\title{
Durum İzleme ve İstatistiksel Süreç Kontrolü Kullanarak Şebeke Kalkışıı Daimi Mıknatısıı Senkron Motorda Rulman Arızası Tespiti
}

\author{
Zafer DOĞAN*, Saadet Gülsüm GöZÜOĞLU \\ Tokat Gaziosmanpaşa Üniversitesi, Mühendislik ve Mimarlık Fakültesi, Elektrik Elektronik Mühendisliği \\ Bölümü, Tokat/TÜRKIYE \\ *zafer.dogan@gop.edu.tr
}

Received/Geliş: 28.02.2020

Accepted/Kabul: 21.04.2020

\begin{abstract}
Öz: Şebeke Kalkışlı Daimi Mıknatıslı Senkron Motor (ŞKDMSM) yüksek verim, yüksek güç faktörü ve kendinden kalkış özelliklerinden dolayı bant sistemleri, fan sistemleri gibi endüstriyel ortamlardaki birçok uygulamada kullanılmaktadır. ŞKDMSM arızalarının erken tespiti, üretim kayıplarını ve yüksek bakım onarım giderlerini ortadan kaldıracaktır. Bu çalışmada ŞKDMSM'nin rulman arızalarının tespiti için SCADA tabanlı gerçek zamanlı durum izleme ve arıza tespit yöntemi önerilmiştir. Bu amaçla öncelikle motor akım ve gerilim verilerinin izlenmesi için SCADA tabanlı durum izleme otomasyonu gerçekleştirilmiştir. Sağlam bir ŞKDMSM'den farklı devir ve yük koşulları altında izlenen akım sinyallerinin üstel ağırlıklı hareketli ortalama (ÜAHO) tabanlı bir istatistiksel proses kontrol yöntemi ile analiz edilerek motorun normal çalışma limitleri belirlenmiştir. Daha sonra arıza durumundaki bir ŞKDMSM'nin akım sinyallerine ait ÜAHO verileri kullanılarak bu limitlerin aşımlarına göre arıza tespiti yapılmıştır. Elde edilen sonuçlar tasarlanan SCADA otomasyonunun güvenli veri toplama ve kaydetme özelliğine sahip olduğunu ve önerilen arıza tespit yönteminin ise ŞKDMSM'nin rulman arızalarının tespiti için başarılı bir araç olduğunu göstermiştir.
\end{abstract}

Anahtar kelimeler: Şebeke Kalkışlı Daimi Mıknatıslı Senkron Motor; SCADA; Üstel Ağırlıklı Hareketli Ortalama; Rulman arizası.

\section{Bearing Fault Detection by Using Condition Monitoring and Statistical Process Control in Line Start Permanent Magnet Synchronous Motor}

\footnotetext{
Abstract: Line start permanent magnet synchronous motor (LSPMSM) is used in many applications in industrial environments such as belt systems and fan systems due to its high efficiency, high power factor and self-starting features. Early detection of LSPMSM failures will eliminate production losses and high maintenance and repair costs. In this study, SCADA-based online condition monitoring and fault detection method is proposed for detecting bearing failures of LSPMSM. For this purpose, SCADA based condition monitoring automation was carried out primarily to monitor motor current and voltage data. The normal operating limits of the motor were determined by analyzing the current signals monitored under different speed and load conditions from a healthy LSPMSM with an exponential weighted moving average (EWMA) based statistical process control method. Then, fault detection was made according to the exceeding of these limits by using EWMA data of the current signals of a the LSPMSM in case of faulthy. The obtained results showed that the designed SCADA automation has the ability to collect and save data safely, and the proposed fault detection method is a successful tool for the detection of bearing failures of LSPMSM.
}

Keywords: Line start permanent magnet synchronous motor; SCADA; EWMA; Bearing Fault. 


\section{Giriş}

Asenkron motor (ASM), günümüz endüstriyel sahalarında mekaniksel güç üretimi için en çok kullanılan motordur [1]. ASM'nin en önemli tercih nedenleri, yapısal olarak basit ve ekonomik olması, periyodik bakım gerektirmemesi, güvenilir olması ve şebekeden doğrudan beslenebilmesidir. Buna karşın, hacimsel olarak büyüklüğü, veriminin daimi mıknatıslı senkron motora (DMSM) göre düşük olması, gürültülü çalışması bu motorun önemli dezavantajlarındandır [2]. DMSM, ASM'ye göre daha verimli olmasına rağmen şebekeden doğrudan beslenemez ve pahalıdır. Bu nedenle DMSM endüstriyel sahada doğrudan ASM yerine tercih edilmez [3, 4]. Motor üreticileri son yıllarda bu iki motorun üstün özelliklerini bir araya getirebilecek bir motor üretme çalışmalarına girmiştir. Bu çalışmalar sonucunda DMSM'nin mıknatıslı rotoruna ASM'nin kafes yapısı eklenerek Şebeke Kalkışı Daimi Mıknatıslı Senkron Motor (ŞKDMSM) elde edilmiştir [5]. ŞKDMSM; kafesli rotoru sayesinde tıpkı ASM'ler gibi, şebekeden doğrudan beslenerek kalkış yapabilirken, sürekli rejimde rotor yapısında bulunan mıknatıslar sayesinde DMSM'ler gibi yüksek verim sağlayabilmektedir. Bu önemli özelliklerinin yanı sıra, hacim/ağırlık oranına göre yüksek güç eldesi, hassas ve kararlı kontrol imkânı, yüksek moment gibi avantajlarıyla ŞKDMSM, endüstrinin birçok alanında ASM'ye rakip olmaya adaydır [6].

İşletme altında limitlerini aşan çeşitli zorlamalardan dolayı ŞKDMSM'lerde arızalanmalar görülür. Oluşan bu arızalar elektriksel, mekaniksel ve manyetik arızalar olarak gruplandırılmaktadır. Bu motordaki elektriksel arızalar; sargı arızaları, rotor çubuk kırığı arızası ve rotor çubuk halkası kırığ1 arızası, mekaniksel arızalar; eksenden kaçıklık ve rulman arızaları, manyetik arızalar ise demagnetizasyon arızası ve mıknatıs kırı̆̆ı arızasıdır [1,6,7]. Arızalı olan motorun çalışma ömrü de kısadır. Arızanın erken tespiti ve ortadan kaldırılması hem motorun tahrik ettiği sistem hem de ekonomik açıdan önemlidir. Erken arıza teşhisi için günümüzde durum izleme yoluyla motorların işletme altındaki çalışmaları gözlemlenmektedir. $\mathrm{Bu}$ sayede, motora ait arızalar başlangıç aşamasında tespit edilebilmekte, arızanın sebep olacağı önemli ekonomik kayıplar önlenebilmektedir. Elektrik motorlarının online durum izlemelerinde; sıcaklık, hava aralığ momenti, akustik ses, titreşim, motor akımları, manyetik akı, indüklenen gerilim, kısmi deşarj, gaz, ani elektrik gücü, ani açısal hız gibi birçok veri kullanılmaktadır: Bunlar içerisinde en pratik olan ve en yaygın kullanılanı motor akımlarıdır [7].

Motor arızalarının tespitinde en önemli nokta motora ait sinyalleri temsil eden özelliklerin elde edilmesidir. Özellik çıkarma esasında bir sinyale ait en baskın özelliklerin hesaplanarak sinyalin sayısallaştırılmasıdır [8]. Elektrik makinaları arızalarına ait sinyal özellikleri elde etmede en çok kullanılan yöntemler, frekans boyutunda analiz, zaman-frekans boyutunda analiz ve zaman boyutunda analizdir [9]. Bu analizler içerisinde zaman boyutunda analizler diğerlerine nazaran daha çok kullanılmaktadır. Çünkü bu analiz yöntemi karmaşık algoritma ve dönüşümler gerektirmediğinden hem pratiktir hem de hızlı arıza tespiti yapma imkanı sunar. Zaman boyutunda analizlerde çoğunlukla sinyale ait istatistiksel özellikleri çıkartılır. Bu şekilde sinyal özellikleri üreten yöntemlerden biri de İstatistiksel Süreç Kontrol (ISSK) yöntemidir. İSK, sinyallerin istatistiksel özellikleri yoluyla süreç takibi, arıza belirleme, kalite kontrol vb. uygulamalarda kullanılmaktadir [10,11].

İSK yöntemi, literatürde birçok çalışmada kullanılmıştır. Yaptığı tez çalışmasında Boston (2010), İSK yöntemini kullanarak bir askeri kuruluşa ait araçların motor yenileme sürecinde hataların önlenmesi, işçilik ve malzeme kayıplarının düşürülmesi sağlanmıştır [12]. Alağaş ve Pınarbaşı (2012), düz dişlilerdeki hataların sebep olduğu titreşimlerdeki değişimlerin incelenerek, farklı tipteki diş kusurlarından ve kusur tiplerinden elde edilen verilerin iki yönlü (x,y) analiz edilerek tespiti için İSK yönteminden yararlanmışlardır. Dişlinin aşınma zamanının tespiti için, İSK yöntemlerinden olan Üstel Ağırlıklı Hareketli Ortalama (ÜAHO) kontrol grafiğini oluşturmuş ve yorumlamıştır [10]. Eser (2018), ASM'nin stator sargı arızası tespiti için İSK yöntemini 
kullanmıștır. Kararlı durum motor akım sinyalleri üzerinden bu yöntemi kullanarak arızayı tespit etmiştir [13]. Djmal ve ark(2018). optimize ÜAHO yöntemini kullanarak atık su arıtma tesisinde suların temizlenmesini kontrol etmişlerdir. Bu yöntemin çok küçük değişiklikleri ortaya çıkarabilme özelliğinden faydalanarak arıtma sürecindeki verimi arttırmışlardır [11]. He ve Yu (2019) kararlı robotik kaynak işlemi için ÜAHO üzerinden arıza tespiti ve teşhisini başarıyla gerçekleştirmişlerdir [14].

$\mathrm{Bu}$ çalışmada tasarlanan SCADA tabanlı durum izleme otomasyonu kullanılarak ŞKDMSM'nin rulman arızası tespit edilmiştir. Önerilen arıza tespit yöntemi, ŞKDMSM stator akım sinyalleri üzerinden ÜAHO yoluyla özellik çıkarmaya dayalıdır. Önerilen yöntem ŞKDMSM'nin arıza tespiti için ilk kez kullanılmıştır. Durum izleme amacıyla tasarlanan SCADA sistemin donanımsal bölümünün merkezinde mikro denetleyici olarak Arduino Mega kullanılmıştır. Arduino Mega Remote Terminal Unit (RTU) gibi görev yapmaktadır. Donanıml bölümü, sensör verilerini toplayan, düzenleyen ve SCADA ara yüzüne aktaran ve aynı zamanda SCADA ara yüzünden gelen komutları donanım bölümüne gönderen yapıdır. Donanım bölümü vasıtasıyla motordan alınan stator akım sinyalleri SCADA ortamında izlenmekte ve ÜAHO yöntemi kullanılarak arıza tespiti yapılmaktadir.

Bu makale 5 bölümden oluşmaktadır. Makalenin devam eden 2. bölümü ŞKDMSM matematiksel modeli, SCADA Sistemi ve İstatistiksel Süreç Kontrol bilgilerini içeren Materyal ve Metot bölümüdür. Üçüncü bölüm Deneysel Çalışmalar bölümü olup, deney düzeneği ve veri toplama bilgilerini içermektedir. Çalışmalara ilişkin Bulgular ve Tartışma 4. Bölümde verilmiştir. Beşinci bölüm Sonuç ve Önerileri içermektedir.

\section{Materyal ve Metot}

\section{1. Şebeke Kalkışıı Daimi Mıknatıslı Senkron Motor Modeli}

ŞKDMSM'ler ASM'lerin ve DMSM'lerin en üstün özelliklerini taşıyan hibrit motorlardır. Yapısal olarak ASM stator yapısına sahip olup, rotorda ASM'nin kafes yapısına ilaveten DMSM rotorunda bulunan daimi mıknatıslar eklenmiştir. Bu motor kalkış anında yaklaşık asenkron tork ile yol alırken sürekli durumda mıknatıs torku ile senkron çalışır. Bu nedenle ŞKDMSM'ler arada evirici olmadan doğrudan șebekeyle beslenebilirler. Bu motor sürekli halde çalıșırken klasik senkron motorun performansina sahiptir [15].

Rulman arızaları gibi mekanik arızalar motorda titreşimlere, yük değişimlerine ve hava aralığında akı değişimlerine sebep olurlarken, motor akımlarında da harmonikler oluştururlar. Bütün bunların sonucunda ise motor torkunda salınımlar ortaya çıkar. Motorların arıza durumlarının motor parametreleri üzerine etkisini incelemede matematiksel modelleri kullanmak etkin bir yaklaşımdır $[1,5,16]$. Matematiksel modeller motorların fiziksel davranışlarının belirlenmesinde ve arıza tespitinde kullanılabilirler. Rulman arızası durumundaki bir ŞKDMSM modeli için sağlam durum matematiksel model öncelikle bilinmelidir. Bu motorun matematiksel modeli $d$-ekseni, $q$-ekseni ve sıfır bileşen dikkate alınarak çıkartılabilir [16]. Şekil 1'de ŞKDMSM'ye ait eşdeğer devreler gösterilmiştir. 


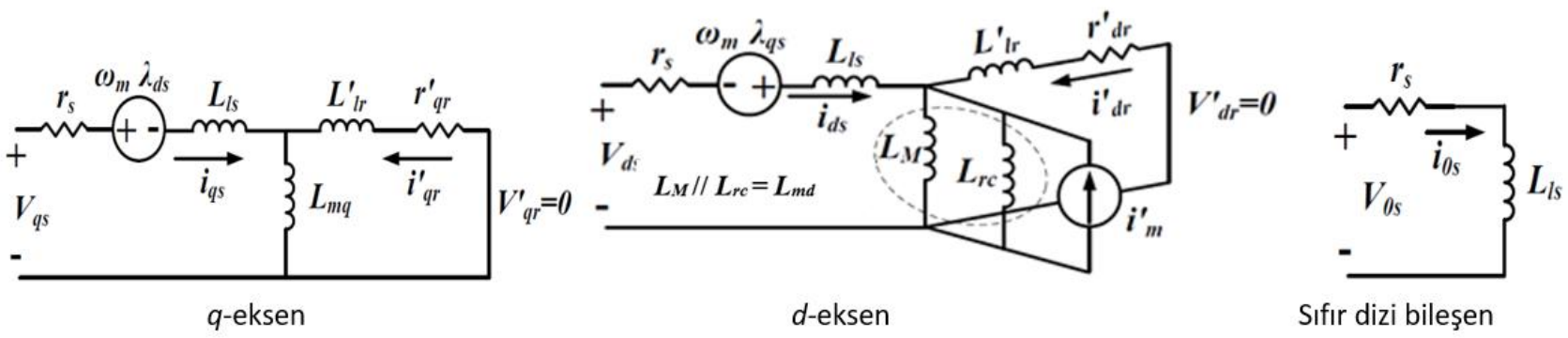

Şekil 1. Üç fazlı ŞKDMSM'nin $q$ - eksen, $d$ - eksen ve sıfır bileşen eşdeğer devreleri [12]

ŞKDMSM'de daimi mıknatıslarında oluşan rotor eddy akım kayıpları ihmal edilerek, motorun eşdeğer mıknatıslanma akısı $\lambda_{m}$ eşitlik 1 ile hesaplanabilir.

$$
\lambda_{m}=L_{m d_{m}} i_{m}^{f}
$$

Burada, $i_{m}^{\prime}$ mıknatıslanma akımını ve $L_{m d}$ mıknatıslanma indüktansını göstermektedir. Kirchoff gerilim yasası dikkate alınarak yazılan, ŞKDMSM'de $d$ - $q$ ve 0 bileşenler devreler için stator gerilimi $v_{d s}^{r}, v_{q s}^{r}, v_{0 s}^{r}$, rotor gerilimi $v_{q r}^{r_{r}}$ ve $v_{d r}^{r_{r}}$, sırasıyla eşitlik 2 ve eşitlik 3 'te:

$$
\begin{gathered}
v_{q s}^{r}=r_{s} i_{q s}^{r}+\omega_{m} \lambda_{d s}^{r}+p \lambda_{q s}^{r} \\
v_{0 s}^{r}=r_{s} i_{0 s}^{r}+p \lambda_{0 s}^{r} \\
v_{q r}^{f r}=r_{q r}^{f} i_{q r}^{f r}+p \lambda_{q r}^{f r}=0 \\
v_{d r}^{g r}=r_{d r}^{g} i_{d r}^{f r}+p \lambda_{d r}^{g r}=0
\end{gathered}
$$

olarak yazılabilir. $\mathrm{Bu}$ ifadelerde $r_{s}$, stator direnci, $r_{q r}^{\prime}$ ve $r_{d r}^{\prime}$ rotor direnci, $L_{m q}$ ve $L_{m d}$ mıknatıslanma indüktansı, $L_{l r}^{s}$ rotor kaçak indüktansı, $L_{l s}$ stator kaçak indüktansı ve $\omega_{m}$ açısal hızdır. Motorun stator akısı $\lambda_{q s}^{r}, \lambda_{d s}^{r}, \lambda_{0 s}^{r}$, rotor akısı $\lambda_{q r}^{t_{r}}, \lambda_{d r}^{t_{r}^{r}}, \lambda_{0 r}^{t_{r}^{r}}$ sırasıyla eşitlik 4 ve eşitlik 5'te verilmiştir.

$$
\begin{aligned}
& \lambda_{q s}^{r}=L_{I s} i_{q s}^{r}+L_{m q}\left(i_{q s}^{r}+i_{q r}^{r}\right) \\
& \lambda_{d s}^{r}=L_{l s} i_{d s}^{r}+L_{m d}\left(i_{d s}^{r}+i_{d r}^{r}\right)+L_{m d} i_{m}^{b} \\
& \lambda_{0 s}^{r}=L_{l s} i_{0 s}^{r} \\
& \lambda_{q r}^{t_{r}^{r}}=L_{l r}^{p} i_{q r}^{t_{r}}+L_{m q}\left(i_{q s}^{r}+i_{q r}^{p^{r}}\right)
\end{aligned}
$$

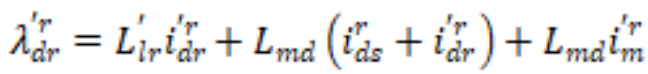

$$
\begin{aligned}
& \lambda_{0 r}^{i r}=L_{l r}^{p} i_{0 r}^{i r r}
\end{aligned}
$$

Burada; $i_{d s}, i_{q s}, i_{0 s}$ stator akımları, $i_{q r}^{t r}, i_{d r}^{I r}, i_{0 r}^{J r}$ rotor akımlarıdır. Sonuç olarak $P$ kutup sayıs1 olmak üzere, motorun arıza durumunu değerlendirmek için kullanılacak tork değeri eşitlik 6 ile hesaplanabilir. 


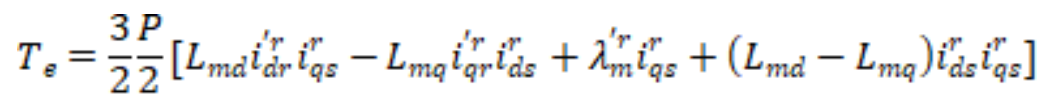

\subsection{SCADA Sistemi}

SCADA sistemleri günümüzde havaalanları, fabrikalar, elektrik üretim tesisleri vb. birçok alanda kullanılmaktadır. SCADA tesis edildiği ortamlarda tüm alt birimleri kontrol eden ve izleyen merkezi bir sistemdir. Temel işlevleri sistem kontrolü, izleme ve veri toplamadır. SCADA sistemlerinde sistem kontrolleri yapılabildiğinden, endüstriyel ortamlardaki motorların online izlenmesi ve arıza tespitinde de etkin bir şekilde kullanılabilmesine olanak sağlamıştır. Motor arızalarında erken arıza teşhisi sayesinde önemli donanım hasarları ve ekonomik kayıplar önlenebilir. Bu nedenle motorda ortaya çıkan arıza kritik bir noktada ise SCADA sistemi ile motor işletmeden alınabilir. Motor korumasında olduğu gibi elektrik şebekelerinin kontrolü ve arıza takibinde de SCADA sistemleri kullanılmaktadır [17]. Şekil 3'te SCADA için tasarlanan sisteminin genel şeması görülmektedir.

Şekil 2'den görüldügü gibi, bir SCADA sistemi, bilgileri toplayan RTU bölümünden, bilgilerin analiz edilmesini sağlayan SCADA ara yüzünden ve veri tabanından oluşmaktadır [20].

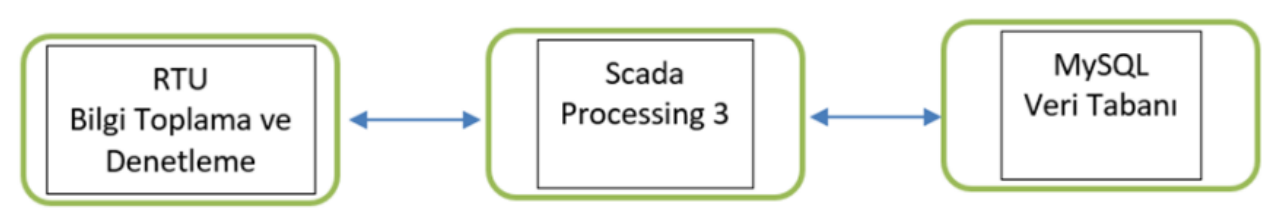

Şekil 2. SCADA için tasarlanan sisteminin genel şeması.

Bu çalışmada, ŞKDMSM'nin rulman arızası tespiti için tasarlanan SCADA sisteminin donanımsal bölümünün temelini Arduino Mega oluşturmaktadır. Arduino Mega içerisinde ATmega2560 çip barındıran, 54 dijital giriş-çıkış, 16 analog giriş pinine sahip olan ve 256kB'lık geniş bir hafızası bulunan bir mikrodenetleyicidir. Motor akım sinyallerinin izlenmesi için 5A ölçüm yapabilen akım sensörü kullanılmıştır. Bu sensör çalışma şekli $5 \mathrm{~A} / 5 \mathrm{~mA}$ şeklinde olup çıkış pinlerine $\mathrm{RB}=200 \Omega$ örnekleme direnci bağlanmıştır. Bu sayede hem akım trafosu açık uçlu kalmamış hem de algılayıcı çıkış işareti ölçümü değerlendirecek olan Arduino analog giriş yapısına uygun olarak gerilim biçimine dönüştürülmüştür. Motora uygulanan gerilimlerin izlenmesi amaciyla, $250 \mathrm{~V}$ rms ölçüm yapabilen 2mA/2mA gerilim sensörü kullanılmıştır. Bu devrede 16x2 LCD ekran, DS3231 gerçek zaman modülü ve röle modülü yer almaktadır. LCD ekran ölçüm ve değerlendirme sonuçlarının SCADA ara yüzünde görüntülenmesini sağlamaktadır. DS3231 gerçek zaman modülü I2C iletişim protokolü kullanarak mikro denetleyici ile iletişim sağlamakta ve ara yüze gönderilen verilerin zaman etiketi ile aktarılmasını sağlamaktadır. Zaman ile ilgili uygulanabilecek senaryolarda bu modül kullanılabilmektedir. Röle modülü, mikro denetleyici dijital çıkışlarından birine bağlanmış ve motor koruması sağlanırken gerekli durumda motorun enerjisiz kalmasını sağlamak için kullanılmıştır. Kullanmış olduğumuz kontrol yönteminde arıza durumunda isteğe bağlı olarak motorun durdurulması gerektiğinde röle modülü bu görevi yerine getirmektedir.

Mikro denetleyici içerisinde yer alan yazılım iki modda çalışmaktadır [17]. 1. çalışma modunda; ara yüzden gelen talebe göre elde edilen örnekleme verilerini kullanarak pozitif tepe noktalarını yazılım ortamına gönderir ve ÜAHO için veri sağlar. 2. çalışma modunda; örnekleme verilerini ve "Emonlib" kütüphanesini kullanarak akım, gerilim ve güç değerleri gibi sistemin anlık durumunu kullanıcıya sunmaktadır. Yazılım olarak Processing 3 ve Wamp Server kullanılmıştır. Processing ortamı özellikle mikro denetleyici çalışmalarında entegreye gömülü halde bulunan, kullanıcı tarafından görülemeyen verilerin görüntülenmesini ve kolay bir şekilde kontrol etmesini sağlayan 
Java tabanlı bir ortamdır. Çalışmada kullanılan SCADA ara yüzü seri iletişim yolu ile mikro denetleyiciden gelen veri paketlerini alıp değerlendirecek şekilde Processing ortamında hazırlanmıştır. SCADA arayüz uygun Port Adı ve Baud Rate seçilerek mikro denetleyici ile online olarak iletişimde olduğu gibi Wamp Server yazılımı kullanılarak MySQL veri tabanıyla da iletişimini sağlamaktadır. Tasarlanan SCADA'nın Şekil 3a'da donanımsal kontrol birimi, Şekil 3b'de arayüzü görülmektedir.

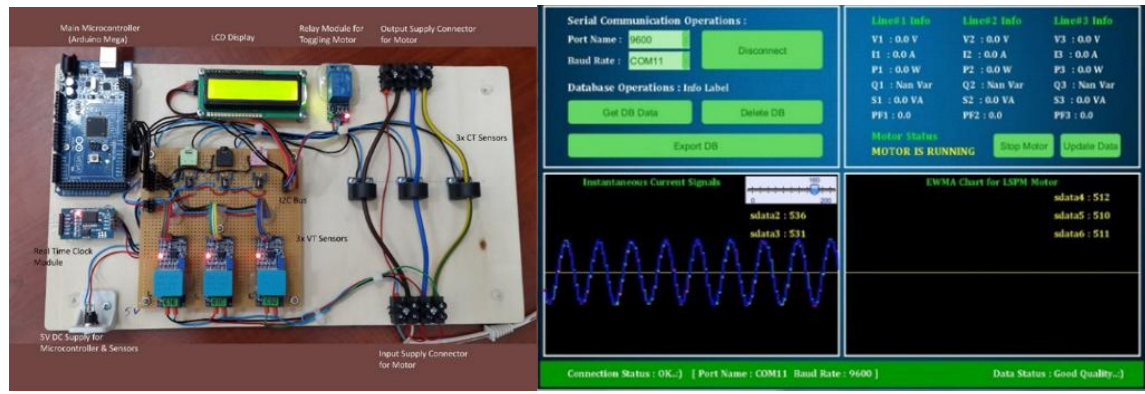

Şekil 3. (a) SCADA Ara yüzü (b) Donanımsal Kontrol Birimi

Processing ortamında hazırlanmış olan SCADA arayüzünün, donanımsal bölümden verileri alabilmesi için belirli kurallar oluşturulmuştur. Kullanıcı komut girdisi ile Arduino veriyi doğrulayarak seri iletişimi başlatır ve arayüze veri aktarılır. Wamp Server kullanılarak oluşturulan MySQL veri tabanına arayüze ulaşan veriler kaydedilir. Kaydedilen bu veriler ÜAHO için giriş verisi olarak kullanılmaktadır. Veri tabanında oluşturulan tablolar giriş verilerinin kaydedilmesini sağladığı gibi analizler sonucunda elde edilen karar değerlerinin de kaydedilmesini sağlamaktadır. Böylece geçmişe yönelik analizler ve raporlamalar da kolaylıkla yapılabilmektedir.

\section{3. İstatistiksel Süreç Kontrolü}

İSK işleyen bir süreç içerisinde normalin dışında oluşan en ufak değişikliklere bağlı olarak farklılığı ortaya çıkartan bir yöntemdir[18]. Normal durum içerisinde hesaplanan değerler limit değerlerini içerisinde salınım yapmaktadır. Ancak bu değerler limit değerlerini aşmaları durumunda sürecin normal dişı oluşan değişikliği ortaya çıkar[19]. Yedi temel İSK yöntemi vardır. Bunlar çetele tablosu, histogram, pareto analizi, sebep-sonuç diyagramı, hata yoğunluk diyagramı, serpilme diyagramı ve kontrol grafikleridir. Bunlar içerisinde kontrol grafikleri pratik olmaları ve güvenilir sonuçlarıyla ön plana çıkmaktadır. Kontrol grafikleri bir süreçte olağan üstü değişiklikleri izlemek için kullanılır. Gelelenksel kontrol grafiklerinde hatayı en aza indirmek için verideki otokolerasyonu kaldırmak gerekir. Bu amaç için zaman serisi modeller tabanlı yaklaşımlar [20], ÜAHO ve çok değişkenli Ü̈AHO yöntemleri [21] araştırmacılar tarafından kullanılmıştır. ÜAHO diğer yöntemlere göre en önemli avantaj1 tek bir değişkene bağlı olarak süreç takibi yapabilmektedir ve son derece güvenilir sonuçlar verebilmektedir. Şekil 4'te ÜAHO İSK grafiği görülmektedir.

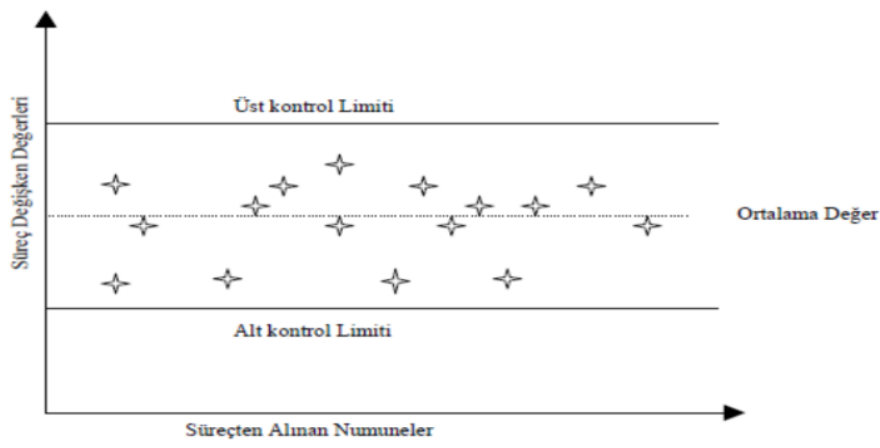

Şekil 4. ÜAHO İSK grafiği [13] 
ÜAHO'da, merkez çizgi (MÇ) ile bunun altına ve üstüne çizilen, alt kontrol limit (AKL) ve üst kontrol limit (ÜKL) çizgileri bulunmaktadır. MÇ salınımın hangi düzlemde olması gerektiğini belirtirken AKL ve ÜKL ise salınım alanını ifade etmektedir. Bu alan dışına çıkılması durumunda arıza veya normal olmayan durum teşhis edilmiş olur $[22,23]$. ÜAHO limit değerleri çeşitli istatistiksel ifadelerle hesaplanır. Öncelikle veriye ait alt grupların genel ortalaması hesaplanır. $k$ alt grup sayısı, $n \mathrm{~h}$ er bir alt grupta bulunan ölçüm sayısı, $x_{i j}$ değeri $i$ alt grubundaki $j$ numaralı örnekleme değeri olmak üzere, alt grubunun ortalaması $x_{i}$ eşitlik 7'de, tüm alt grupların ortalaması eşitlik 8'de gösterilmiştir [21].

$$
\begin{aligned}
& \overline{x_{i}}=\frac{\sum_{j=1}^{n} x_{i j}}{n} \\
& \overline{\bar{x}}=\frac{\sum_{i=1}^{k} \overline{x_{i}}}{k}
\end{aligned}
$$

Daha sonra standart sapma ve genel ortalama hesaplanır. Her bir alt grubun standart sapma değeri $\left(s_{i}\right)$ ve genel ortalaması sırasıyla eşitlik 9 ve eşitlik 10 'a göre hesaplanır.

$$
\begin{gathered}
s_{i}=\sqrt{\frac{\sum_{i=0}^{n}\left(x_{i}-\bar{x}\right)^{2}}{n-1}} \\
\bar{s}=\frac{1}{k} \sum_{i=1}^{k} s_{i}
\end{gathered}
$$

ÜAHO aşağıdaki ifadeyle tanımlanır:

$$
z_{i}=\lambda \overline{x_{i}}+(1-\lambda) z_{i-1}
$$

burada $z_{i} i$. ÜAHO istatistiği, $\lambda$ düzeltme parametresidir ve başlangıç değeri $z_{0}=\overline{\bar{x}}$ olarak alınmıştır[21]. Tüm bu ifadeler üzerinden ÜAHO merkez çizgi(MÇ), AKL ve UKL değerleri:

$$
\begin{aligned}
& U K L_{i}=\overline{\bar{x}}+(L \bar{s}) \sqrt{\frac{\lambda}{(2-\lambda)}\left[1-(1-\lambda)^{2 i}\right]} \\
& M C=\overline{\bar{x}} \\
& A K L_{i}=\overline{\bar{x}}-(L \bar{s}) \sqrt{\frac{\lambda}{(2-\lambda)}\left[1-(1-\lambda)^{2 i}\right]}
\end{aligned}
$$

olarak hesaplanır. Burada $L$ sabit değerdir.

\section{Deneysel Çalışmalar}

\subsection{Deney Düzeneği}

Bu çalışmada ŞKDMSM'nin online durum izlemesi ve rulman arızalarının tespiti için SCADA sisteminin metodolojisi; veri izleme ve toplama, sinyal işleme ve arıza tespiti aşamalarından oluşmaktadır. Önerilen SCADA tabanlı online durum izleme ve arıza tespit sistemine ait deney düzeneği ve blok şema Şekil 5 'te görülmektedir. 


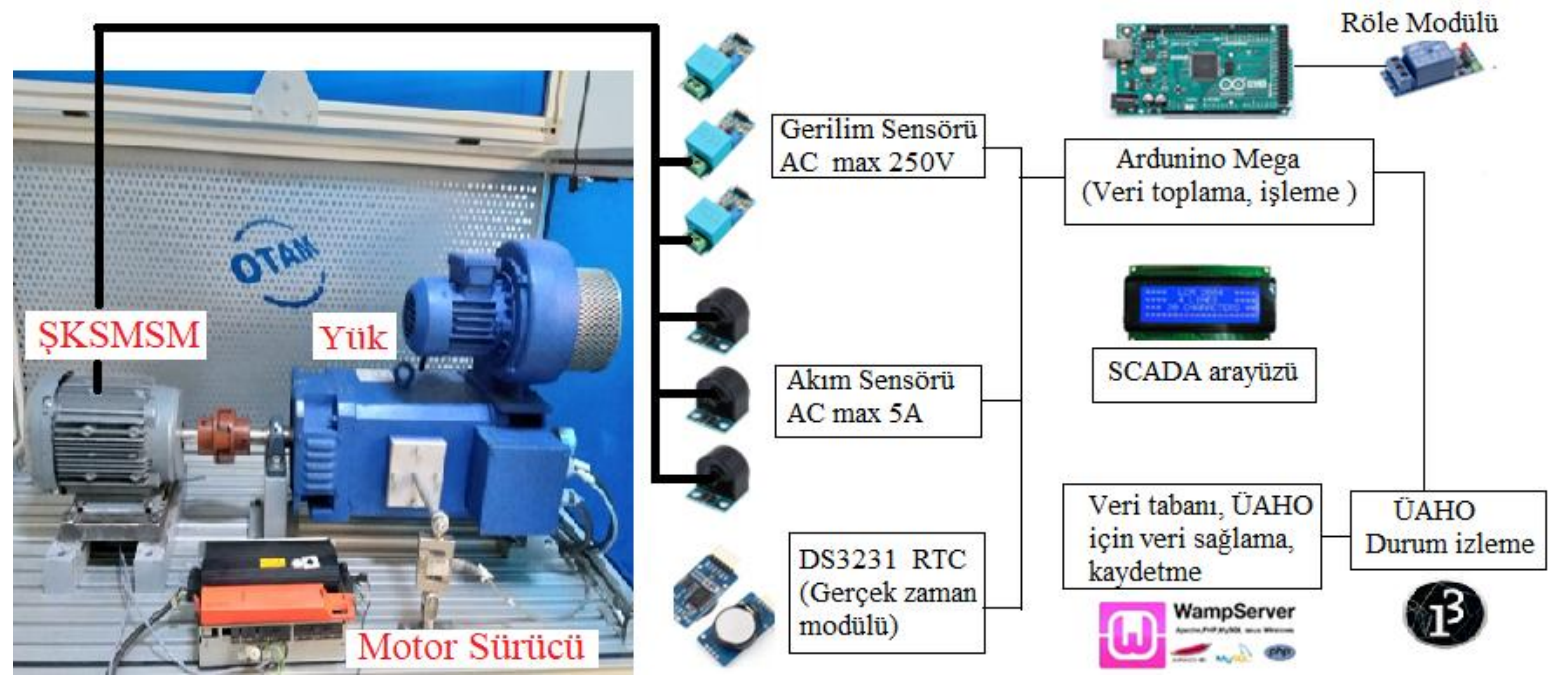

Şekil 5. Durum izleme ve arıza tespit sistemine ait deney düzeneği ve blok şema

Yukarıda görülen blog şemadaki sistemde akım sensörleri üzerinden alınan akım sinyalini mikro denetleyiciye aktarır. Sinyal tepe noktaları mikro denetleyicide uygun paketler şeklinde düzenlenip seri iletişim yolu ile SCADA ara yüzüne taşınır [24]. Ara yüz kendisiyle uyumlu olarak çalışan veri tabanına bu değerleri kaydetmektedir. ÜAHO grafik analizini gerçekleştirmek için kayıtlı olan bu verileri kullanmaktadır. Burada ÜAHO analizi her grupta toplamda 500 adet veri kullanılmıştır.

Deney düzeneği; motor, yük ve motor sürücüden oluşmaktadır. Burada yük olarak $10 \mathrm{~kW}$ güçte bir DC makine, motorun düşük devir deneylerinin yapılabilmesi için $3 \mathrm{~kW}, 380 \mathrm{~V}, 0-6000 \mathrm{rpm}$ parametrelere sahip 3 fazlı bir sürücü kullanılmıştır. Sağlam ve arızalı motor durumları için Tablo 1 'de parametreleri görülen 2 adet özdeş ŞKDMSM kullanılmıştır.

Tablo 1. ŞKDMSM parametreleri

\begin{tabular}{ccccccccc}
\hline Güç & Frekans & Gerilim( $(\Delta / \mathbf{Y})$ & $\operatorname{Akım}(\Delta / \mathbf{Y})$ & Hız & $\operatorname{Cos} \varphi$ & $\begin{array}{c}\text { Kutup } \\
\text { Sayısı }\end{array}$ & $\begin{array}{c}\text { \% } \\
\text { Verimi }\end{array}$ & $\begin{array}{c}\text { Koruma } \\
\text { Sinıfi }\end{array}$ \\
\hline $2,2 \mathrm{~kW}$ & $50 \mathrm{~Hz}$ & $230 / 400 \mathrm{~V}$ & $7,10 / 4,10 \mathrm{~A}$ & $1500 \mathrm{~d} / \mathrm{d}$ & 0,85 & 4 & 91,2 & IP 54 \\
\hline
\end{tabular}

Motor arızalarının tespitinde en önemli hususlardan biri, motor verilerinin güvenilir bir şekilde izlenmesidir. Bu nedenle iyi bir deney düzeneği oluşturulmalıdır. Herhangi bir arızanın testleri yapılırken çoklu arıza oluşumuna izin verilmemelidir. $\mathrm{Bu}$ nedenle çalışılan rulman arızalarına ek olarak eksenden kaçıklık arıza durumunun oluşumunu engellemek için, motor ile yük bağlantısında Şekil 6'da görülen lazer şaft hizalama sistemi kullanılmıştır. Böylece rulman arızası durumuna ait motor akım sinyalleri şaft eksen kaçıklığı sorunu olmadan izlenebilmiştir.

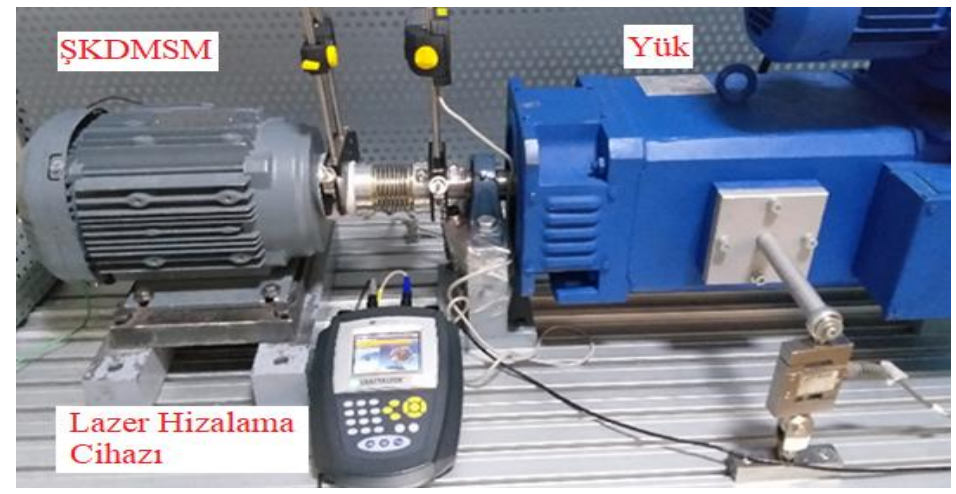

Şekil 6. Deney düzeneği eksenleme 
Yapılan uygulamalarda 3 farklı tipte rulman arızası üzerinde çalışılmıştır: dış bilezik (DB) arızası, iç bilezik (İB) arızası, hasarlı bilye (HB) arızası. Bu arızalar her bir rulmanda yapay olarak üretilmiştir. Şekil 7'de arızalı rulmanlara ait resimler görülmektedir.

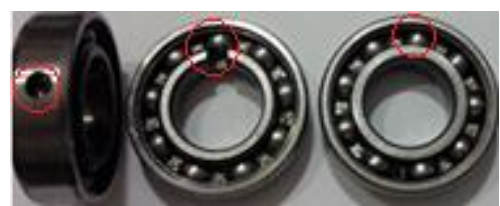

Şekil 7. DB, İB ve HB Arızalı rulmanlar

\subsection{Veri Toplama}

Veri toplama aşamasında motorlar yaklaşık olarak nominal çalışma sıcaklığına gelmesi için 20 dakika çalıştırıldıktan sonra motor akım sinyal verisi bilgisayar ortamında kaydedilmiştir. Önerilen yöntemde arıza tespiti sağlam ve arızalı motor akım sinyal veri setlerinin karşılaştırılmasına dayanmaktadır. Sağlam ŞKDMSM'den alınan akım sinyal verisi ile kaliteli çalışma aralığ 1 oluşturulmakta ve motorun arızalı durumunda alınan veri sürecin devamına işlenerek arızanın varlığ1 tespit edilmektedir.

Stator akım sinyal verisi motorda sağlam durum için iki farklı devirde (500 rpm, $1500 \mathrm{rpm})$, farklı yük durumları (\% 0, \% 100) için toplanmıştır. Motor senkron devir olan $1500 \mathrm{rpm}$ devirde çalışırken şebekeden, düşük devir olan 500 rpm'de çalışırken ise sürücüden beslenmiştir. Toplanan verilere örnek olarak; $500 \mathrm{rpm}$ ve $1500 \mathrm{rpm}$ devir ve \% 100'lük yük durumlarının grafikleri Şekil 8 ve Şekil 9'da sunulmuştur.
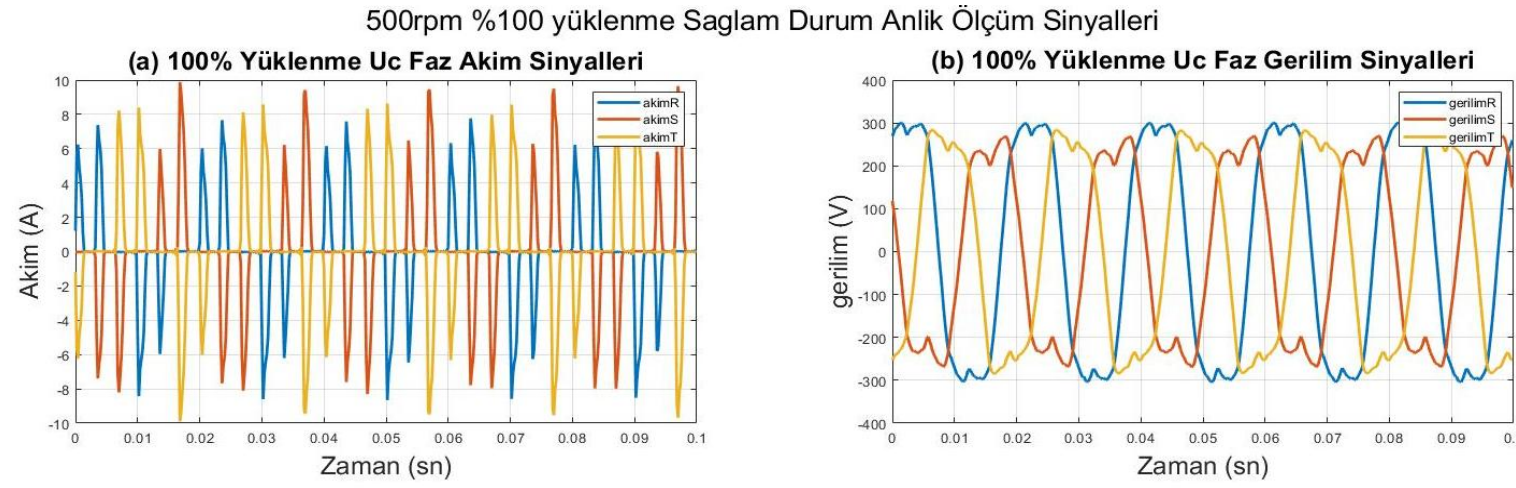

(c) $100 \%$ Yüklenme Tork Sinyali

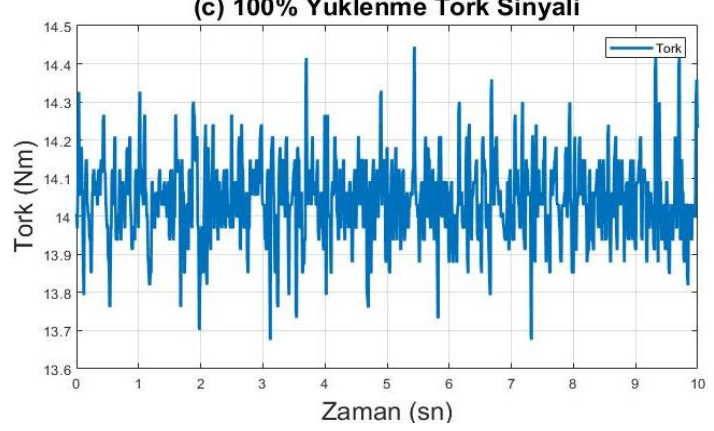

(d) $100 \%$ Yüklenme Motor Hizi

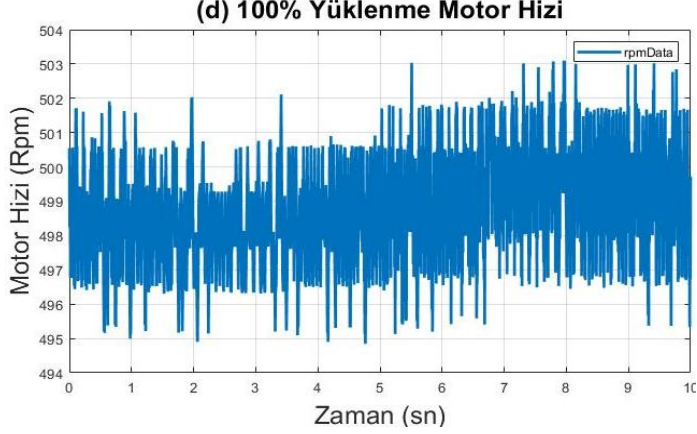

Şekil 8. 500 rpm'de sağlam durum grafikleri 
1500rpm \%100 yüklenme Saglam Durum Anlik Ölçüm Sinyalleri

(a) $100 \%$ Yüklenme Uc Faz Akim Sinyalleri

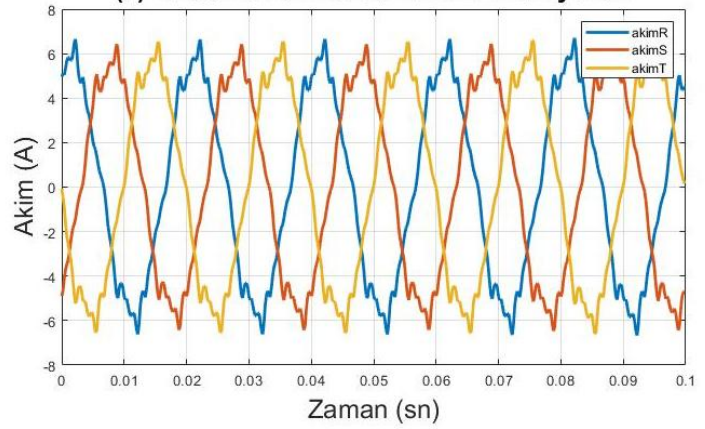

(c) $100 \%$ Yüklenme Tork Sinyali

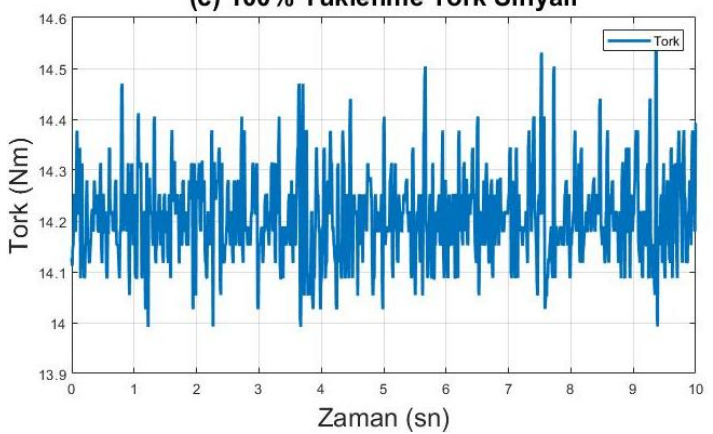

(b) $100 \%$ Yüklenme Uc Faz Gerilim Sinyalleri

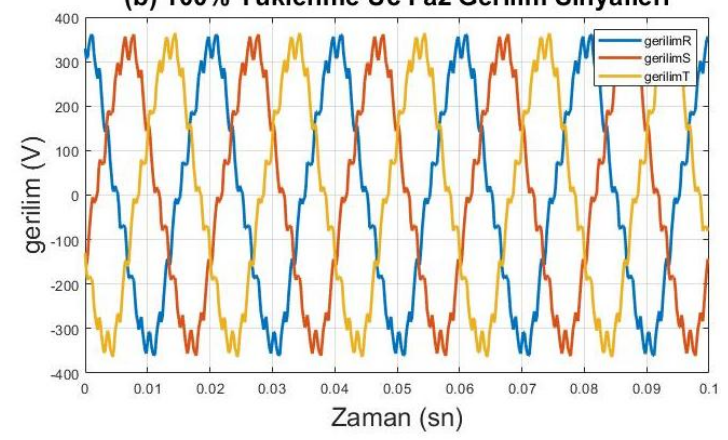

(d) $100 \%$ Yüklenme Motor Hizi

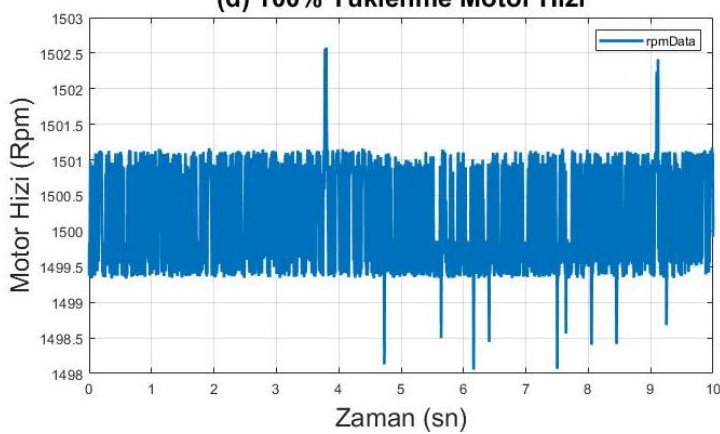

Şekil 9. 1500 rpm'de sağlam durum grafikleri

\section{Bulgular ve Tartışma}

Deneysel çalışmalarda sağlam durum ve her bir arıza durumu akım sinyali izlemeleri, şebekeden beslemeli (1500rpm) ve sürücü beslemeli (500rpm) olmak üzere iki farklı devirde gerçekleştirilmiştir. Öncelikle sağlam durum analizleri yapılıp, ÜAHO grafiklerinin limit noktaları olan, ÜKL, MÇ ve AKL değerleri hesaplanmış ve Tablo 2'de görülen değerler elde edilmiştir.

Tablo 2. ŞKDMSM'nin ÜAHO’ya bağlı kaliteli çalışma limitleri

\begin{tabular}{ccccc}
\hline \multirow{2}{*}{ Limitler } & \multicolumn{2}{c}{ Düşük Hız } & \multicolumn{2}{c}{ Senkron Hız } \\
\cline { 2 - 5 } & Boşta & Tam Yük & Boşta & Tam Yük \\
\hline ÜKL & 601,28 & 721 & 622 & 725 \\
MÇ & 573 & 670 & 606 & 696 \\
AKL & 542,81 & 620 & 591 & 664 \\
\hline
\end{tabular}

Tablo 2'de görülen limitler üzerinde motor akımlarından hesaplanan ÜAHO veri noktaları kullanılarak sağlam durum grafikleri oluşturulmuştur. Daha sonra her bir arıza durumunda hesaplanan ÜAHO veri noktaları sağlam durum grafiklerine eklenmiştir. Elde edilen bu grafiklerde ilk 0-10 arası örnekler sağlam durum, 10. örnekten sonrası ise arıza durumuna aittir. Burada yapılan ilk deneysel çalışmalar motorun DB arızası için yapılmıştır. Şekil 10 ve Şekil 11'de, düşük ve senkron devir çalışmalar için DB arızası ÜAHO grafikleri görülmektedir. 

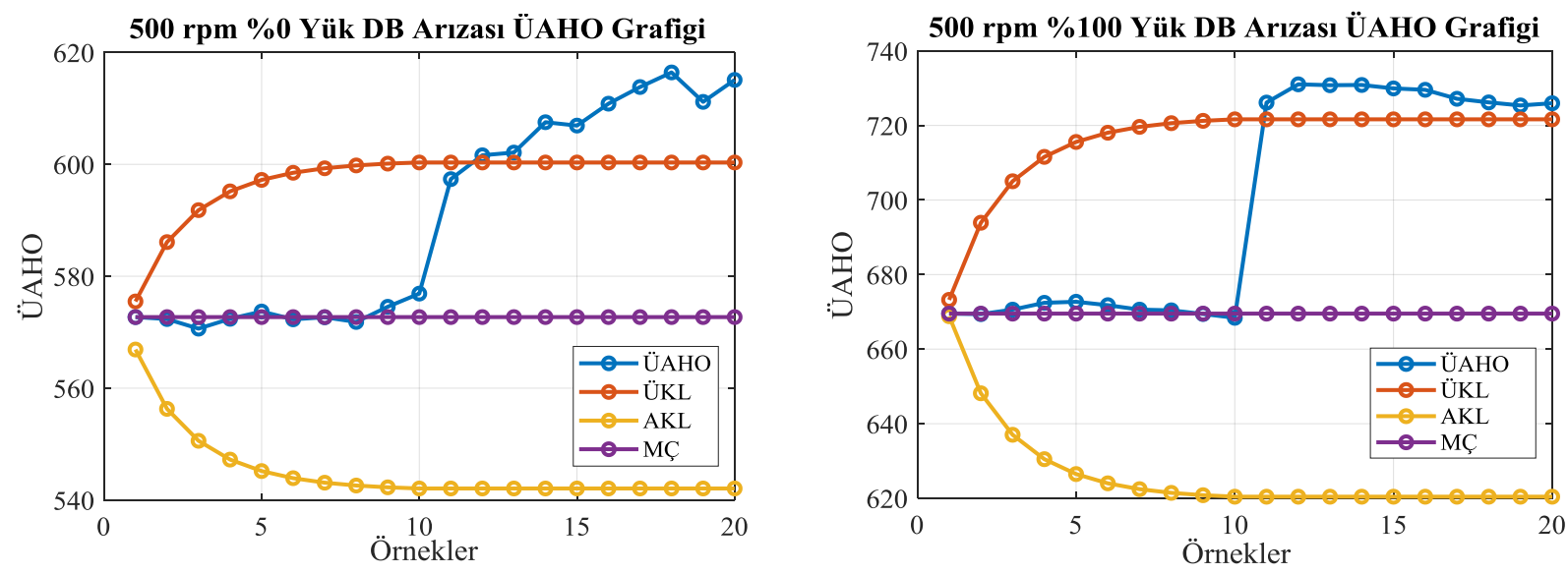

Şekil 10. Düşük devirde (a) \% 0 ve (b) \% 100 yük DB arızası grafikleri
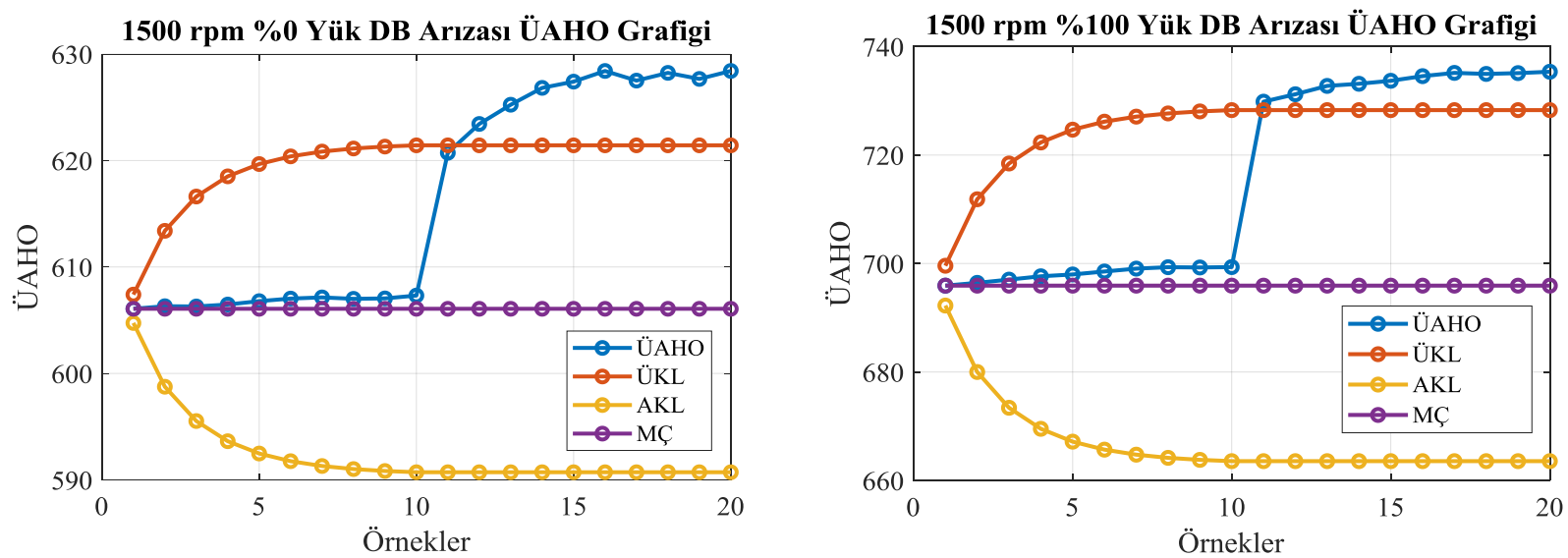

Şekil 11. Senkron devirde (a) \% 0 ve (b) \% 100 yük DB arızası grafikleri

Yukarıdaki grafiklerde 10. örneğe kadar sürecin kaliteli çalışma aralığında devam ettiği görülmektedir. 10. örnekten sonra ÜKL değerini aşıp sürekli artan bir grafik oluşturarak; Şekil 10a'da 615, Şekil 10b'de 730, Şekil 11a'da 628 ve Şekil 11b’de 735 değerlerine ulaşılmıştır.

İkinci olarak yapılan deneysel çalışmalar motorun İB arızası çalışmalarıdır. Şekil 12 ve Şekil 13'te, düşük ve senkron devir çalışmalar için İB arızası ÜAHO grafikleri görülmektedir.
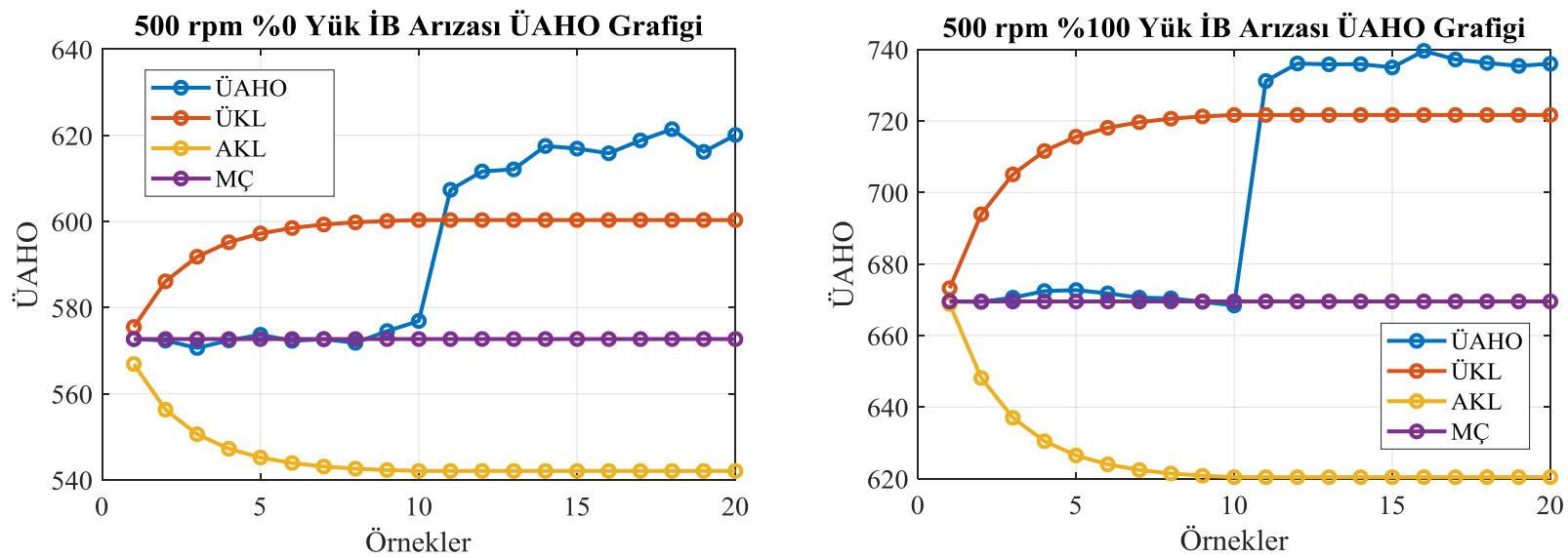

Şekil 12. Düşük devirde (a) \% 0 ve (b) \% 100 yük İB arızası grafikleri 

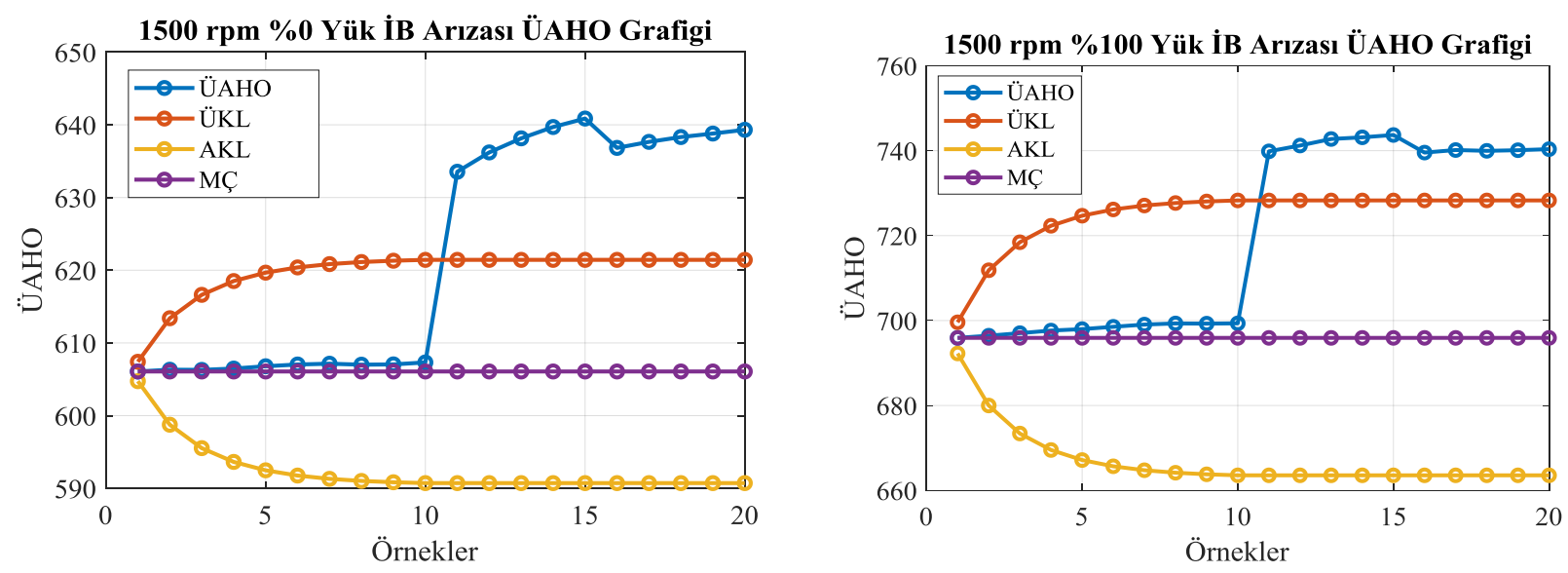

Şekil 13. Senkron devirde (a) \% 0 ve (b) \% 100 yük İB arızası grafikleri

İB arızası grafiklerinde sağlam duruma ait 10. örneğe kadar süreç kaliteli çalışma aralığındadır. DB arıza durumuna ait 10. örnekten sonra ise ÜKL değeri aş1lıp; Şekil 12a'da 620, Şekil 12b'de 740, Şekil 13a'da 640 ve Şekil 13b'de 745 değerlerine ulaşı1mıştır.

Yapılan son deneysel çalışmalar motorun HB arızası çalışmalarıdır. Şekil 14 ve Şekil 15'da, düşük ve senkron devir çalışmalar için HB arızası ÜAHO grafikleri görülmektedir.

Diğer grafiklerdeki gibi, HB arızası grafiklerinde de sağlam duruma ait 10. örneğe kadar süreç kaliteli çalışma aralığındadır. HB arıza durumuna ait 10. örnekten sonra ise ÜKL değeri aşılıp; Şekil 14a'da 612, Şekil 14b'de 712, Şekil 15a'da 628 ve Şekil 15b'de 735 değerlerine ulaşılmıştır.

Tüm bu grafiklerden elde edilen sonuçlardan görüleceği gibi, sağlam durumu temsil eden ilk 10 örnek kaliteli çalışma aralıklarındadır. Arıza durumlarını temsil eden 10. örnekten sonraki noktalar ise ÜKL değerlerini aşmış ve sürekli bu aşım değerlerinde kalmıştır. Bu limit aşımları ile arızalar kolaylıkla tespit edilebilmektedir.
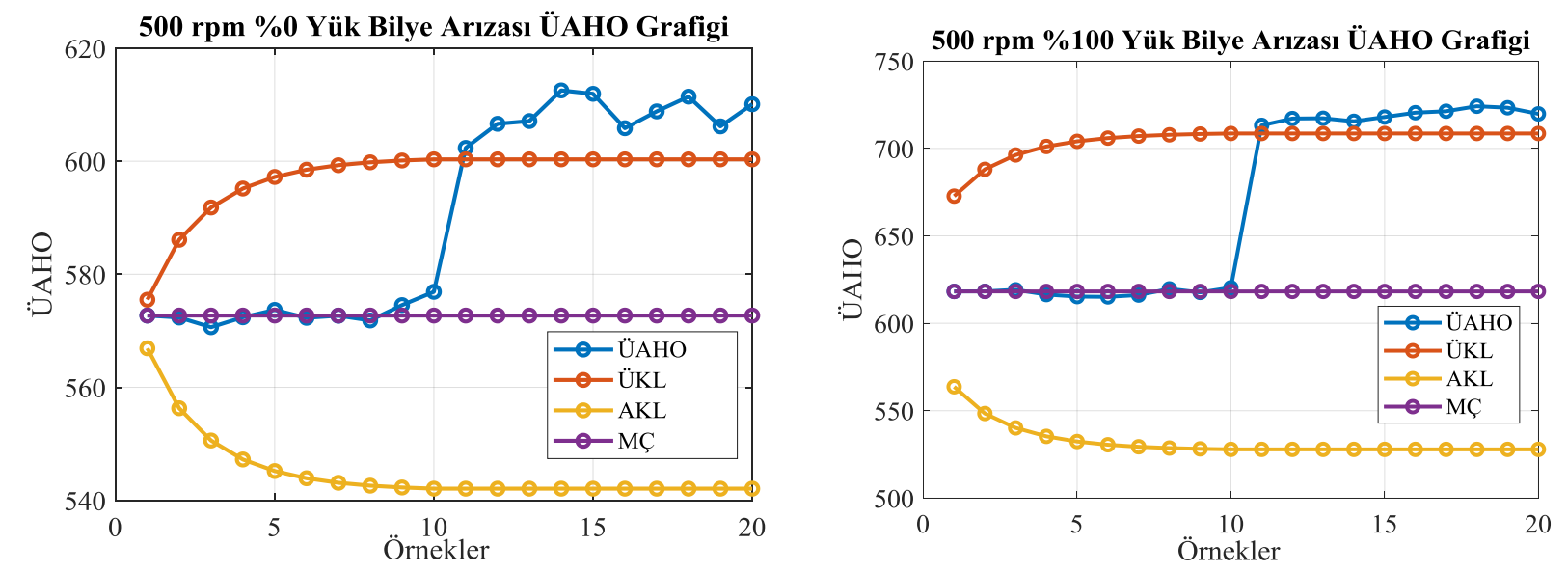

Şekil 14. Düşük devirde (a) \% 0 ve (b) \% 100 yük HB arızası grafikleri 

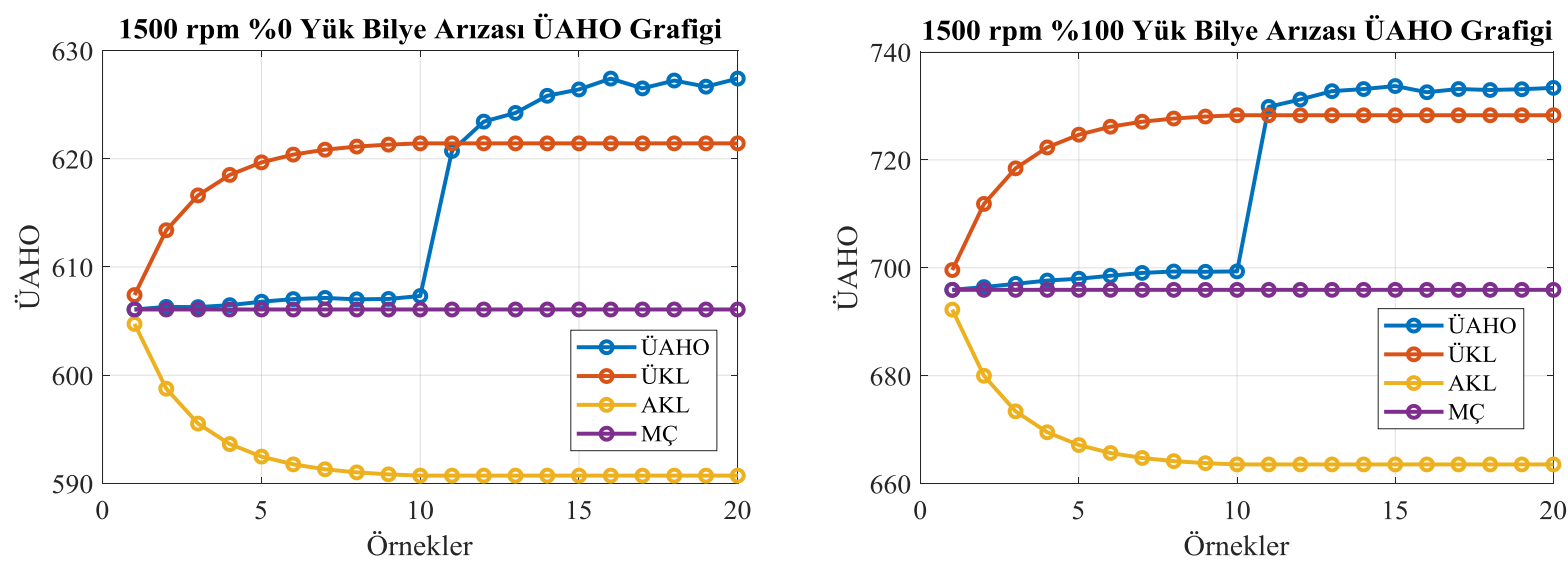

Şekil 15. Senkron devirde (a) $\% 0$ ve (b) $\% 100$ yük HB arızası grafikleri

\section{Sonuç ve Öneriler}

Bu çalışmada ŞKDMSM'nin rulman arızası tespiti için SCADA tabanlı durum izleme otomasyonu gerçekleştirilmiştir. SCADA için kullanılan mikro denetleyicinin düşük maliyetli olması, kolayca yeniden programlamaya müsaade etmesi ve esnek yazılımı, sistemin erişilebilir olmasını sağlamaktadır. Önerilen arıza tespit yöntemi, ŞKDMSM stator akım sinyalleri üzerinden ÜAHO İSK yoluyla özellik çıkarmaya dayalıdır ve bu alandaki literatürde bu motor için ilk kez kullanılmıștır. SKDMSM'nin sağlam durum ve arıza durum (DB, İB, HB) akım sinyalleri farklı hız ve yük koşulları altında donanımsal bölümden alınarak SCADA ortamında izlenmiş ve bir veri kütüphanesine kaydedilmiştir. Sağlam durum akım verisi üzerinde, ÜAHO İSK yöntemi kullanılarak motorun kaliteli çalışma (sağlamlık) limitleri (AKL, ÜKL, MÇ) hesaplanmıştır. Limitler üzerinde motor akımlarından hesaplanan veri noktaları kullanılarak sağlam durum ÜAHO grafikleri oluşturulmuştur. Daha sonra her bir arıza durumunda hesaplanan ÜAHO veri noktaları sağlam durum grafiklerine eklenmiş ve arıza durum ÜAHO grafikleri üretilmiştir. Elde edilen arıza durum ÜAHO grafiklerinde, sağlam durum akım veri noktalarının kaliteli çalışma aralığında iken arıza durumunda bu noktaların ÜKL'lerin dışına çıktıkları görülmüştür. Bu limit aşımları dikkate alınarak arıza tespiti yapılmıştır. Elde edilen sonuçlar önerilen yöntemin rulman arıza tespitinde başarılı bir şekilde kullanılabileceğini göstermiştir.

\section{Teşekkür}

Bu çalışma, Tokat Gaziosmanpaşa Üniversitesi Bilimsel Araştırma Projeleri Birimi tarafından 2018/59 nolu proje ile desteklenmiş̧ir. Bu çalışmanın ortaya çıkmasında verdiği destekten ötürü Bilimsel Araştırma Projeleri Birimine teşekkür ederiz. 10-12 Ekim 2019 tarihlerinde Gaziantep Üniversitesi'nde düzenlenen konferansta sunulan çalışmamın seçiminde TICMET19 organizasyon komitesine çok teşekkür ederiz.

\section{Kaynaklar}

[1]. Yu M., Tao X., Xin D., Xin Z., "Fault diagnosis and numerical simulation of broken rotor bars for small cage induction motors", in 2017 Chinese Automation Congress (CAC), pp. 5355-5359, 2017.

[2]. İlten E., Demirtaş M., "Sınırlı Hafızalı Sistem için Kesirli PI入 Kontrolör Uygulaması". ElCezeri Journal of Science and Engineering, 2018, 5: 237-242.

[3]. Kim K., Kim H. J., Lee J., "Demagnetization Analysis of Permanent Magnets According to Rotor Types of Interior Permanent Magnet Synchronous Motor", IEEE Transactions on Magnetics, 2009, 45: 2799-2802. 
[4]. Wang X., Wang Z., Xu Z., He J., Zhao W., "Diagnosis and Tolerance of Common Electrical Faults in T-Type Three-Level Inverters Fed Dual Three-Phase PMSM Drives." IEEE Transactions on Power Electronics, 2020, 35(2): 1753-1769.

[5]. Behbahanifard H. Sadoughi A., "Line start permanent magnet synchronous motor performance and design; a Review". Journal of World's Electrical Engineering and Technology, 2015, 4(2):58-66.

[6]. Maraaba L., Al-Hamouz Z., Abido M., "An Accurate Tool for Detecting Stator Inter-Turn Fault in LSPMSM", IEEE Access, 2019, 7: 88622-88634.

[7]. Nandi S., Toliyat H. A., Li X., "Condition Monitoring and Fault Diagnosis of Electrical Motors-A Review”, IEEE Transactions on Energy Conversion, 2005, 20: 719-729.

[8]. Proakis J. G., Manolakis D. G., Digital Signal Processing: Principles, Algorithms and Applications, Pentice Hall, 2007, 20-33.

[9]. Boashash, B., "Time-Frequency Signal Analysis. Advances in Spectrum Estimation and Array Processing," S. Haykin, Ed., ed: Prentice- Hall, 1990, pp. 418-517.

[10]. Alağaş H. M., Pınarbaşı M., "Ewma Kontrol Grafikleri İle Düz Dişli Çarklarında İstatiksel Süreç Kontrolü", 13th International Conference on Econometris, Operations Research, and Statics, 2012, Kirıkkale.

[11]. Djmal I. B., Mansouri M., Nounou M., Nounou H., Hamida A. B., "Fault detection using UKF-based optimized EWMA method in wastewater treatment plant", in 2018 4th International Conference on Advanced Technologies for Signal and Image Processing (ATSIP), pp. 1-6, 2018.

[12]. Bostan H., "İstatistiksel proses kontrol tekniklerinin motor yenileştirme sürecinde kullanımı," Yüksek Lisans Tezi, Balıkesir Üniversitesi Fen Bilimleri Enstitüsü, 2010, Balıkesir.

[13]. Eser, E., "Asenkron Motorlarda İstatistiksel Proses Kontrol Yöntemi le Arıza Tespiti," Yüksek Lisans Tezi, Gaziosmanpaşa Üniversitesi, 2018, Tokat.

[14]. He Y., Yu Z., Li J., Ma G., "Weld seam profile extraction using top-down visual attention and fault detection and diagnosis via EWMA for the stable robotic welding process", International Journal of Advanced Manufacturing Technology, 2019, 104:3883-3897.

[15]. Mirimani S. M., Vahedi A., Marignetti F., De Santis E., "Static eccentricity fault detection in single-stator-single-rotor axial-flux permanent-magnet machines", IEEE Transactions on Industry Applications, 2012, 48: 1838-1845.

[16]. Soreshjani M. H., Haghparast M., "Classical Direct Torque Control performance of Line Start PM Synchronous Motor for different conditions", International Transactions on Electrical Energy Systems, 2015, 25:2595-2620.

[17]. Gozuoglu A., Ozgonenel O., "Training Set Design for Smart Grids and Scada CoSimulations", in 2019 7th International Istanbul Smart Grids and Cities Congress and Fair (ICSG), 2019, pp. 124-128.

[18]. Stapenhurst T., Mastering statistical process control, ed Routledge, 2013.

[19]. Niezgoda J., "The use of statistical process control tools for analysing financial statements", Folia Oeconomica Stetinensia, 2017, 17: 129-137.

[20]. Marvuglia A., Antonio M., "Monitoring of wind farms' power curves using machine learning techniques",Applied Energy, 2012, 98: 574-583.

[21]. Yang H-H, Huang M-L., Lai C-M., Jin J-R., "An approach combining data mining and control charts-based model for fault detection in wind turbines", Renewable Energy, 2018, 115:808-816.

[22]. Fugate M. L., Sohn H., Farrar C. R., "Vibration-based damage detection using statistical process control", Mechanical Systems and Signal Processing, 2001,15: 707-721.

[23]. Zerbato C., Furlani C. E., Silva R. P., Voltarelli M. A., Santos A. F. D., "Statistical control of processes aplied for peanut mechanical digging in soil textural classes", Engenharia Agrícola, 2017, 37: 315-322.

[24]. Üstünsoy, F. ve Sayan, H. H.,. PLC Destekli SCADA ile Enerji Yönetimi İçin Örnek Laboratuvar Çalışması. Politeknik Dergisi, 2018, 21(4):1007-1014. 